\title{
La disolución de las Corporaciones Locales como medio de defensa del Estado: un grave atentado contra la autonomía local *
}

\author{
Octavio Salazar Benítez \\ Profesor Titular de Derecho Constitucional \\ Facultad de Derecho, Universidad de Córdoba
}

\begin{abstract}
Sumario: 1. INTRODUCCIÓN. 2. EL CARÁCTER POLÍTICO DE LA AUTONOMÍA LOCAL: LA CAPACIDAD DE INDIRIZZO POLÍTICO DE LOS ENTES LOCALES. 3. LA PREVISIÓN DE CONTROLES DE «LEGALIDAD» PERO NO DE «OPORTUNIDAD». 4. ¿LA DISOLUCIÓN DE LAS CORPORACIONES LOCALES COMO MEDIO DE DEFENSA DEL ESTADO?
\end{abstract}

\section{INTRODUCCIÓN}

Entre las múltiples medidas que integran la Ley Orgánica 1/2003, de 10 de marzo, para la garantía de la democracia en los Ayuntamientos y la seguridad de los concejales ${ }^{1}$, dirigidas a atender la especial situación del País Vasco, cabe destacar el recurso a uno de los mecanismos más extremos previstos por el legislador estatal. Me refiero a la posibilidad, contemplada en el artículo 61 de la Ley 7/1985, de 2 de abril, Reguladora de las Bases de Régimen Local (LRBRL), de disolver las corporaciones locales en caso de gestión gravemente dañosa para los intereses generales. En concreto, el artículo 6 de la Ley añade un nuevo apartado $2^{\circ}$ al artículo 61 LRBRL, según el cual: «Se considerarán, en todo caso, decisiones gravemente dañosas para los intereses generales, en los términos previstos en el apartado anterior, los acuerdos o actuaciones de los órganos que den cobertura o apoyo, expreso o tácito, de forma reiterada y grave, al terrorismo o a quienes participen en su ejecución, lo enaltezcan o lo justifiquen, así como menosprecien o humillen a las víctimas o a sus familiares.

\footnotetext{
* Este texto fue presentado como Comunicación en el Primer Congreso de la Asociación de Constitucionalistas españoles, celebrado en Toledo los días 21 y 22 de noviembre de 2002, momento en el que la LO 1/2003, de 10 de marzo, para la garantía de la democracia en los ayuntamientos y la seguridad de los concejales era sólo una Proposición de Ley. El texto ha sido revisado una vez aprobada y publicada la Ley.

${ }^{1}$ La aprobación de esta ley se sitúa en el marco de una determinada política de aislamiento de los terroristas. Una política que ha tenido su plasmación legal más controvertida en la LO 6/2002, de 27 de junio, de Partidos Políticos, aprobada con el objetivo fundamental de ilegalizar a Batasuna.
} 
Creo que el recurso a la disolución de las Corporaciones locales no sólo supondría un grave atentado contra su autonomía política y su reducción a meros entes administrativos sujetos incluso a controles de oportunidad política, sino que además, más que resolver, vendría a enturbiar la complicada situación de algunos municipios vascos. La «defensa del Estado» implícita en el recurso a esta medida supondría, paradójicamente, el desconocimiento del ámbito de autonomía constitucionalmente garantizado a los municipios y, en definitiva, el atentado contra un modelo de Estado que la Constitución española define en su artículo 137. Como ha señalado Luis ORTEGA, «la organización que predica el artículo 137 es una organización política que expresa articuladamente el modelo constitucional de descentralización política y este modelo preconiza que la soberanía constituida se encuentra repartida en tres niveles políticos de nivel territorial. Por ello, al igual, al igual que las Comunidades Autónomas, también los Entes Locales expresan soberanía en su ámbito autónomo de poder» ${ }^{2}$. Por lo tanto, no cabe establecer una jerarquía política entre los distintos niveles territoriales. Cada uno de ellos es expresión directa de la soberanía. Como más adelante, y con más rotundidad expresa ORTEGA, «la Administración local, al ser directamente representativa de su propia colectividad política, como expresión del pluralismo político territorial, puede elegir sus propios fines, por lo que no está avocada a expresar los fines de la mayoría parlamentaria, ya que la Administración local no forma parte del poder ejecutivo estatal o autonómico» ${ }^{3}$ (cursiva mía).

No vendría mal, pues, recordar el verdadero carácter de la autonomía local en nuestra Constitución, en qué consiste la garantía constitucional de la autonomía local que sería la potencialmente afectada por la disolución de las Corporaciones locales en virtud de sus actos o acuerdos que supusieran un apoyo expreso o tácito al terrorismo. Y es que, como señalara García Morillo, «la Constitución no sólo protege los órganos locales, sino que - sobre todo en lo que a los municipios se refiere- regula las características básicas, reitera su carácter básico y los inviste de unos de los valores superiores del ordenamiento constitucional, el de ser expresiones del pluralismo político y manifestaciones del principio democráti$c o$ en lo referente a los órganos de gobierno de la colectividad» ${ }^{4}$.

\footnotetext{
${ }^{2}$ Luis Ortega, «La potestad normativa local», Anuario de Gobierno Local, 2001, p. 41.

${ }^{3}$ Luis Ortega, op. cit., p. 47.

${ }^{4}$ Joaquín García Morillo, La configuración constitucional de la autonomía local. Marcial Pons. Diputación de Barcelona, 1998, p. 35. En el mismo sentido, Eliseo AJA, «Configuración constitucional de la autonomía local», en Tomás FonT (dir.), Informe sobre el gobierno local. MAP. Fundació Pi i Sunyer. Madrid, 1992, pp. 64 ss.; y Javier GARCíA RocA, «La garantía de la autonomía local de las Corporaciones locales frente a la ley: el conflicto local», en VV.AA., Administracio-
} 


\section{EL CARÁCTER POLÍTICO DE LA AUTONOMÍA LOCAL: LA CAPACIDAD DE INDIRIZZO POLÍTICO DE LOS ENTES LOCALES}

La Constitución Española de 1978 (CE) comienza su Título VIII, dedicado a la Organización Territorial del Estado, con la proclamación de los tres ámbitos territoriales autónomos en los que se organiza aquél: los municipios, las provincias y las Comunidades Autónomas ${ }^{5}$. Entidades que, de acuerdo con el artículo $137 \mathrm{CE}$, «gozan de autonomía para la gestión de sus respectivos intereses» ${ }^{6}$. La Ley 7/1985, de 2 de abril, Reguladora de las Bases de Régimen Local, confirmó la posición del municipio al definirlo en sus artículos 1 y 11 como «la entidad local básica de la organización territorial del Estado».

Tal y como reconociera prontamente el Tribunal Constitucional en su sentencia de 2 de febrero de 1981, el principio de autonomía es «uno de los principios estructurales básicos de nuestra Constitución». De acuerdo con ello, el artículo 137 «refleja una concepción amplia y compleja del Estado, compuesto por una pluralidad de organizaciones de carácter terri-

nes públicas y Constitución. Reflexiones sobre el XX aniversario de la Constitución española de 1978. INAP. Madrid, 1998, pp. 801 ss.

5 Debemos recordar que el Anteproyecto de Constitución incluía la Administración Local en el capítulo II del Título V, dedicado al Gobierno y la Administración. A partir del Informe de la Ponencia se mantuvo la ubicación actual. Sobre el proceso constituyente véanse M. ArAGón, «El tratamiento constitucional de la autonomía local», Organización territorial del Estado (Administración Local). Vol. I. I.E.F. Madrid, 1985, pp. 470-473; y S. Martín-Retortillo, «Las Corporaciones locales en el Anteproyecto de Constitución», Revista de Estudios de la Vida Local, n. ${ }^{\circ}$ 197, 1978, pp. 9-26. Las Constituciones de nuestro entorno recogen también la autonomía local dentro del Título dedicado a la organización territorial del Estado. Es el caso de la Constitución italiana (arts. 5, 114, 128, 130), la alemana (art. 28) y la francesa (art. 24.9 y 72). Véase al respecto J. L. MeILÁn GIL, «La articulación de los ordenamientos local y autonómicos», Revista Española de Derecho Administrativo, n. ${ }^{\circ}$ 44, 1984, pp. 666-667. También las consideraciones de J. Leguina VILLA en Escritos sobre autonomías territoriales. Tecnos. Madrid, 1984, pp. 257 ss.

${ }^{6}$ La redacción de este artículo recuerda el art. 8 de la Constitución de 1931 que también encabezaba el Título dedicado a la organización territorial del Estado; en concreto, el II, titulado «Organización nacional». Dicho artículo establecía que «El Estado español, dentro de los límites irreductibles de su territorio actual, estará integrado por Municipios mancomunados en provincias y por las regiones que se constituyan en régimen de autonomía». Sobre la evolución histórica del régimen local español, véanse A. PosADA, Evolución legislativa del régimen local en España. Madrid, 1910. Reimpresión de IEAL. Madrid, 1982; S. Martín-Retortillo (dir.), volumen I de La descentralización administrativa y organización política. Alfaguara. Madrid, 1973; con una amplia bibliografía, J.A. SANTAMaría PAStor, Fundamentos de Derecho Administrativo, I. Ed. Centro de Estudios Ramón Areces. Madrid, 1988, pp. 1122 ss.; Martín Bassols Coma, «Administración Local», Diccionario del sistema político español. J.J. GonZÁlez Encinar (ed.). Akal. Madrid, 1984, pp. 10-12; Javier García Fernández, El origen del municipio constitucional. I.E.A.L. Madrid, 1983. 
torial, dotadas de autonomía», las cuales constituyen «elementos arquitecturales indispensables del orden constitucional» ${ }^{7}$. Es decir, las autonomías locales son, en los mismos términos que las Comunidades Autónomas, elementos de la organización territorial del Estado ${ }^{8}$. Ambas autonomías poseen la misma naturaleza. Únicamente difieren en su alcance y en la distinta capacidad de configuración social que les ha otorgado el constituyente ${ }^{9}$. Por lo tanto, no cabe considerar las corporaciones locales como escalones jerárquicamente subordinados a las Comunidades Autónomas ${ }^{10}$. El Tribunal Constitucional lo dejó claro en uno de sus primeros pronunciamientos. En su Auto 13/80 (FJ 2) subrayó que «los Ayun-

\footnotetext{
${ }^{7}$ La relevancia de la determinación contenida en el art. 137, y su desarrollo en los arts. 140, 141 y 142, deriva de su pertenencia a la estructura definitoria del Estado. L. PAREJo Alfonso, Derecho básico de la Administración Local. Ariel. Barcelona, 1988, p. 105. En el mismo sentido J. M. BANDRÉs SÁNCHEZ CRUZAT que considera la autonomía local como «principio jurídico vertebrador de la organización de los poderes territoriales locales del Estado». «Comunicación» en J. GARCíA MoRILLO, La configuración constitucional de la autonomía local, cit, p. 86. Véase también Luis ORTEGA, «El pluralismo político como criterio de reparto del ejercicio del poder público», Revista de la Facultad de Derecho de la Universidad Complutense, n. ${ }^{\circ} 4$ (monográfico), 1981. Como ha remarcado Javier GARCíA RocA, «debe revalorizarse la importancia de este artículo, ya que es el dintel de todo el título VIII, la norma que fija el basamento en el que el resto de las disposiciones constitucionales deben comprenderse antes de ser interpretadas». «El concepto actual de autonomía local según el bloque de la constitucionalidad», Revista de Estudios de la Administración Local y Autonómica (en adelante, REALA), n. ${ }^{\circ}$ 282, enero-abril 2000, p. 27.
}

${ }^{8}$ Luciano Parejo Alfonso, «Estado autonómico y Régimen Local», Revista Andaluza de Administración Pública, n. ${ }^{\circ}$ 44, abril-junio 2001, p. 29.

9 L. Parejo Alfonso, «La autonomía local en la Constitución», Tratado de Derecho Municipal. (S. Muñoz Machado, dir.), Vol. I. Civitas. Madrid, 1988, pp. 40-41. Como bien ha resumido José Ángel MARín GÁmEZ, «el pluralismo territorial que la Constitución consagra no se agota en los poderes políticos superiores, lo que significa que la distribución territorial del poder, es decir, la descentralización en sentido lato comprende toda la secuencia de decisiones y acciones del poder público, siendo el último escalón de la secuencia el nivel local, donde ha de buscarse la función constitucional específica de la autonomía local en tanto que locus y forma de administración idóneos para la mejor realización de las exigencias simultáneas del complejo Estado social y democrático de Derecho, por sus especiales condiciones de cercanía a los ciudadanos y aptitud para la participación inmediata de éstos en los asuntos públicos». «El pluralismo territorial presupuesto del gobierno y la autonomía local», en Silvio Gambino y Gerardo RuIz-Rico, Formas de gobierno y sistemas electorales. Tirant lo Blanch. Valencia, 1997, pp. 714-715.

10 «Las Comunidades Autónomas, las Diputaciones y los Ayuntamientos son organizaciones territoriales (art. $137 \mathrm{CE}$ ), con capacidad jurídica propia y centro final de imputación de sus competencias, derechos y deberes. Tanto los Municipios, como las Provincias y las CCAA son Corporaciones territoriales de Derecho Público, todas ellas "jurídico-cualitativamente" iguales.» A. Gallego Anabitarte, Constitución y personalidad jurídica del Estado. Tecnos. Madrid, 1992, p. 47. Enrique SÁNChEZ GoYanes aporta varios argumentos, incluso de tipo histórico, para rechazar la idea de que las Corporaciones locales sean meras entidades administrativas frente a las CCAA. La potestad normativa del municipio español. Ordenanzas, reglamentos, planes urbanísticos, normas. El Consultor de los Ayuntamientos y Juzgados. Madrid, 2000, p. 40. 
tamientos son los órganos a los que, constitucionalmente, corresponde el gobierno y administración de los Municipios; son, en consecuencia, poderes públicos en el sentido del artículo 53.1 de la Constitución y deben ser equiparados a los órganos de la Administración del Estado o de las Comunidades Autónomas, como resulta claramente del texto del apartado 2 del artículo 41 de la LOTC» ${ }^{11}$.

Al margen de esta caracterización, la Constitución Española de 1978 nos ofrece pocos elementos, aunque decisivos, para componer una definición constitucional de «municipio». Hay que tener presente que el capítulo dedicado a la «Administración Local», el segundo del Título VIII, es muy breve. La CE siguió así la opción habitual en nuestra historia constitucional, en la que tan sólo la Constitución de Cádiz incluyó una regulación más amplia de la autonomía local. Opción, por otra parte lógica, si tenemos en cuenta que la principal preocupación del constituyente español del 78 fue la solución del problema regional ${ }^{12}$.

De la escasa regulación constitucional pueden deducirse los siguientes principios configuradores del régimen local:

1. La condición de los Municipios como entes públicos y territoriales que integran el Estado ordenamiento dotados de autonomía (artículo 137 y 140), y de medios suficientes para el desempeño de sus funciones mediante tributos propios y la participación en los del Estado y las Comunidades Autónomas (artículo 142);

\footnotetext{
11 «Conforme al art. $137 \mathrm{CE}$, todas las instancias de la organización territorial del Estado son traducción de la compleja estructura de la comunidad político-administrativa que se constituye en dicho Estado y, por tanto, tienen una idéntica posición y función constitucionales para la realización del pluralismo político en su vertiente territorial, diferenciándose únicamente por la entidad misma de la concreta comunidad que institucionalizan y, por ello, tanto de los intereses colectivos para cuya gestión sirven, como de las potestades-competencias otorgadas para esta gestión». L. Parejo Alfonso, «El régimen jurídico de la Administración Local, hoy», El sistema político local: un nuevo escenario de gobierno, Carlos R. Alba y F. J. Vanaclocha. Universidad Carlos III, BOE. Madrid, 1997, p. 369. No faltan autores que tratan de diferenciar esa posición. Así, por ejemplo, Luis Morell considera que mientras que las regiones y nacionalidades están vinculadas al «modo de ser del Estado», las Corporaciones locales representan «el ámbito más inmediato de integración de la sociedad civil». Luis Morell OCAÑA, «La Administración Local en la Constitución», Administraciones Públicas y Constitución, cit, p. 785.

12 Sobre la poca atención prestada por el constituyente a los «entes territoriales menores», véase el comentario del art. 137 CE realizado por R. Entrena Cuesta en Comentarios a la Constitución. Fernando Garrido Falla (Coord.). Civitas. Madrid, 1980, p. 1487. Es unánime la opinión de que «el espacio local ha sido considerado como un área marginal en la estructuración del Estado autonómico». Rafael JimÉnEZ AsEnsio, «La forma de gobierno local: ¿cambio o continuidad?», Anuario de Gobierno Local, 1999/2000, p. 138.
} 
2. la consagración del pluralismo territorial como valor (artículo 137), aunada a la función de defensa del interés local al Gobierno y Administración locales (artículo 140);

3. la ordenación de ese Gobierno conforme al principio democrático representativo (artículo 140) ${ }^{13}$.

A estas prescripciones habría que sumar la definición de autonomía local que realiza la Carta Europea de Autonomía Local de 15 de octubre de 1985 (en adelante, CEAL), que constituye un referente indispensable para la concreción de lo que debe entenderse por «autonomía local» y para una interpretación adecuada del gobierno local ${ }^{14}$. La CEAL se integra en el «bloque de la legalidad estatal» constitutiva de la cabecera del ordenamiento interno local, asegurando en todo el territorio el mínimo común de autonomía garantizada constitucionalmente a los entes locales. En la medida en que se considere que la LRBRL forma parte del «bloque de la constitucionalidad», también lo integra la CEAL, si bien ésta despliega un efecto incluso más intenso que la ley básica estatal ${ }^{15}$. La Constitución, los Estatutos de Autonomía, la Ley de Bases de Régimen Local y la legislación sectorial atributiva de competencias a los entes locales deben ser interpretados conforme a dicha Carta. Pues bien, según el artículo 3 CEAL por autonomía local debe entenderse «el derecho y la capacidad efectiva de las Entidades locales de ordenar y gestionar una parte importante de los asuntos públicos, en el marco de la ley, bajo su propia responsabilidad y en beneficio de sus habitantes».

De acuerdo con estos principios, comparto la definición dada por Javier García FernándeZ, según la cual el municipio es «un elemento de la estructura orgánica del Estado cuya actuación se dirige a gestionar sus

\footnotetext{
${ }^{13}$ García Roca considera estas normas finalistas o de principio como «el basamento de un edificio». «El concepto actual de autonomía local según el bloque de constitucionalidad», cit., p. 34. Véanse al respecto Javier GarCía FernÁNDEZ, «La autonomía del Derecho político municipal. Fundamentos dogmáticos en la Constitución Española», Organización territorial del Estado. Administración Local. Instituto de Estudios Fiscales. Madrid. 1985, p. 1402; y Antonio Fanlo LoRAS, Fundamentos constitucionales de la autonomía local. C.E.C. Madrid, 1990.
}

${ }^{14}$ La CEAL fue firmada en Estrasburgo el 15 de octubre de 1985, siendo aprobada y ratificada el 20 de enero de 1988 (BOE, $\mathrm{n}^{\circ} 47$ de 24 de febrero de 1989). Entró en vigor el 1 de marzo de 1989. Sobre la CEAL véanse J. Tornos MAS, «Por un sistema de control de la Carta Europea de la Autonomía Local», REALA. № 255-256, julio-diciembre 1992, pp. 815-825; L. Ortega Álvarez, «La Carta Europea de Autonomía Local y el ordenamiento local español», REALA. № 259, julio-septiembre 1993, pp. $475 \mathrm{ss}$.

15 J. M. Rodríguez Álvarez, La Carta Europea de Autonomía local, Bayer Hnos. Barcelona, 1997, pp. 107 y 111. 
intereses mediante las técnicas jurídico-públicas de gobierno y administración, con criterios autonómicos y democrático-representativos, con un alcance material que se fijará por ley, que en todo caso habrá de garantizar la autonomía, la representatividad democrática y la suficiencia financiera» ${ }^{16}$.

Esta definición nos apunta que el municipio no constituye simplemente un escalón de las estructuras administrativas del Estado, sino que es una «comunidad política plena». Diversos rasgos confirman este carácter: la electividad de todos los cargos municipales, incluyendo al alcalde que siempre emana, directa o indirectamente, del censo electoral; los sistemas de participación popular que van más allá de la simple concurrencia electoral; la atribución de competencias materialmente políticas con un alcance extenso y definido; la garantía constitucional de la autonomía municipal; la no inserción de la organización local en la jerarquía administrativa del Estado y los sistemas de tutela basados en el control estricto de legalidad y destinados a proteger el deslinde de competencias ${ }^{17}$.

Son muchas las páginas que sobre todo administrativistas han escrito sobre el carácter de la autonomía local, la mayor parte de ellas condicionadas por el análisis conjunto de las CCAA y de los municipios en cuanto elementos de la organización territorial del Estado. Gran parte de las reflexiones se han hecho sobre la diferenciación del grado de autonomía de que disponen unas y otros ${ }^{18}$, la cual el propio Tribunal Constitucional confirmaría en su primera jurisprudencia. Así, la STC 25/81, de 14 de julio, reconoció que las Comunidades Autónomas gozaban «de una autonomía cualitativamente superior a la administrativa que corresponde a los entes locales, ya que se añaden potestades legislativas y gubernamentales que la configuran como autonomía de naturaleza política» ${ }^{19}$.

\footnotetext{
16 Javier García Fernández, La autonomía del Derecho Político municipal, cit., p. 1402.

17 Javier García Fernández, La autonomía del Derecho Político municipal, cit., p. 1395.

18 Por ejemplo, Luis Morell Ocaña en una reciente contribución sobre la autonomía local comienza diciendo que «Los Municipios y Provincias, con las Islas, constituyen la Administración Local. Su autonomía, no es política, como la de las Comunidades Autónomas, sino meramente administrativa». Y, en ese mismo trabajo, más adelante, incluye un epígrafe titulado «El autogobierno local», en el que vincula éste fundamentalmente a la idea de participación ciudadana. «La Administración Local en la Constitución», VV.AA., Administraciones Públicas y Constitución, cit., pp. 785 y 793. Esta posición, cuando menos contradictoria, ya la había desarrollado con anterioridad en su obra La Administración Local (Tecnos. Madrid, 1984) en la que, pese al título, reconoce que las entidades locales no pueden considerarse sólo como Administraciones públicas, llegando incluso a titular una de sus partes «El autogobierno de la comunidad como dimensión esencial de la Autonomía Local» (p. 46).
}

19 Previamente el TC ya había dejado claro la concepción de la autonomía como un «poder limi- 
De acuerdo con este planteamiento, la línea de distinción es muy clara. Los entes locales tendrían una autonomía de carácter administrativo, mientras que la de las Comunidades Autónomas, al disponer de potestad legislativa y gubernamental, sería de carácter político ${ }^{20}$. El elemento clave de esta distinción estaría en la posesión o no de potestad legislativa, pues también los entes locales tienen potestades gubernamentales, ya que la propia CE atribuye a los Ayuntamientos «el gobierno y la Administración» de los Municipios (artículo 140) ${ }^{21}$. Las Comunidades Autónomas serían, pues, «comunidades políticas plenas» en el sentido de que tienen reconocida la capacidad de ordenación social mediante normas con el valor y la fuerza de leyes. Los entes locales, por el contrario, carecerían de esa capacidad de disposición mediante leyes en sentido formal.

Pese a esa jurisprudencia, y si bien podemos admitir un diferente alcance de la autonomía de los entes locales y de las Comunidades Autónomas, es imposible negar el carácter político que tiene la primera. Porque, «si bien es cierto que la autonomía municipal, como poder para la gestión de sus respectivos intereses, debe ejercerse en el marco del ordenamiento, siendo la ley en definitiva la que concreta el principio de autonomía de cada tipo de entes, ... no puede desconocerse en los municipios la existencia de un cierto "componente político"..., siendo precisamente ese componente político el motor de la vida municipal y cuyo respeto en cierta

tado» y no identificable con la «soberanía», subrayando el equilibrio sobre el que se construye nuestro sistema de organización territorial: «... dado que cada organización territorial dotada de autonomía es una parte del todo, en ningún caso el principio de autonomía puede oponerse al de unidad, sino que es precisamente dentro de éste donde alcanza su verdadero sentido, como expresa el art. 2 de la Constitución» (STC 4/1981, de 2 de febrero, Fundamento jurídico $3^{\circ}$ ).

${ }^{20}$ Sin embargo, creo que habría que puntualizar esta afirmación. Tal y como nos recuerda SosA WAGNER, «sin desconocer ni minusvalorar el distinto grado de la autonomía local y de la autonomía comunitaria, hay que convenir que aquélla no puede quedar reducida al componente administrativo, de la misma forma que ésta tampoco queda reducida al componente político. Ambos componentes (bien que con intensidades distintas) pueden existir en sendas autonomías y de hecho existen justo en la medida en que devienen elementos constitutivos de los respectivos intereses». «La autonomía local», Estudios sobre la Constitución Española. Homenaje al prof. Eduardo García de Enterría. S. Martín-Retortillo (coord.). Tomo IV. Civitas. Madrid, 1991, p. 3211.

21 «Por ello, no basta con plegarse a la cómoda inercia y seguir manteniendo que hay una autonomía política y otra administrativa porque la primera implica la potestad legislativa, y ésta falta en las Corporaciones locales. Eso, en todo caso, sería un efecto, no sería la causa. Más aún: sería el efecto de una interpretación de la autonomía local por el Tribunal Constitucional que ha conducido al absurdo antes advertido (...) en la Ley fundamental ni está explícita la causa de tales efectos diferenciadores ni tampoco proclamada en ella una distinción cualitativa en la naturaleza jurídica de unas y otras Corporaciones públicas: unos y otra son el fruto de la doctrina por la que ha optado el TC en su exégesis de la autonomía local,...» Enrique SÁnchez Goyanes, La potestad normativa del municipio español. Ordenanzas, reglamentos, planes urbanísticos, normas, cit., p. 40. 
manera garantiza la Constitución, no pudiendo ser desconocido por el Estado en ningún caso, y sólo por razones de defensa de los intereses nacionales que le están encomendados podrá el Poder del Estado limitar dicha iniciativa municipal, sin que sea admisible en la actualidad cualquier otro control patrocinado por razones de tutela o estructura jerárquica...» (STS de 3 de febrero de 1987) ${ }^{22}$.

Evidentemente, una cosa es que la autonomía de los entes locales no sea meramente administrativa, y otra distinta es que dicha autonomía tenga un carácter limitado y, por tanto, se hallen sometidos a las leyes del Estado y de la correspondiente Comunidad Autónoma. Aspectos que con frecuencia se han confundido en la misma jurisprudencia. Así, por ejemplo, la STS de 16 de septiembre de 1993 interpretaba la autonomía municipal como «simplemente administrativa y por ello de carácter limitado, pues los entes locales se encuentran sometidos a las leyes del Estado y de la correspondiente Comunidad Autónoma» ${ }^{23}$.

Lo que sí parece fuera de toda duda es que la autonomía local no sólo es gestión administrativa de servicios o mera autoadministración local. El Preámbulo de la LRBRL habla expresamente de inequívoca sustancia política de las entidades locales. Y es que la autonomía local supone también «dirección política propia, potestad normativa primaria, competencias definidas y atinentes al interés local, autonomía financiera o de gasto - más que de ingreso- autonomía funcionarial, un Gobierno representativo de los vecinos que encabeza la Administración local, y responsabilidad política ante el electorado. Todas estas notas exorbitan con mucho del habitual entendimiento del llamado régimen local como autonomía administrativa» ${ }^{24}$.

El carácter político de la autonomía local sólo puede discutirse si se mantiene una identificación estricta entre «autonomía política» y «potestad legislativa» ${ }^{25}$. En nuestro sistema constitucional dicha potestad sólo

\footnotetext{
22 En este mismo sentido se pronuncia SANTAMARÍA PASTOR, cuando afirma que la consideración de los entes locales como Administraciones Públicas es incompleta «si no se contemplara sobre el telón de fondo que constituye el carácter político, auténticamente constitucional, que dichas corporaciones poseen.» J. A. Santamaría Pastor. Fundamentos de Derecho Administrativo, I., cit., p. 1134.

${ }^{23}$ Como ha subrayado SÁnchez Morón, «la Constitución no identifica la autonomía local con la separación de una esfera de actividad reservada por entero a las administraciones locales, con exclusión de toda incidencia de otros niveles de gobierno y de gestión de los intereses públicos. No impone una concepción de la autonomía como absoluta libertad de decisión...». La autonomía local. Antecedentes históricos y significado constitucional. Civitas. U. Complutense. Madrid, 1990, p. 201.

${ }^{24}$ De esta manera, lo que en un Municipio puede ser conveniente puede no serlo en otro. GarCíA RocA, «El concepto actual de autonomía local...», cit., p. 52.
} 
pertenece al Estado y a las Comunidades Autónomas, si bien ello no impide que los órganos de gobierno de los ayuntamientos puedan aprobar determinadas normas dentro del marco dibujado por el «sistema jurídico bifronte» al que están sometidos y que en todo caso ha de ser respetuoso con el margen de autonomía que les reconoce la Constitución ${ }^{26}$. En este sentido, deberíamos recordar la conocida cita de KeLSEN según la cual «los órganos del municipio pueden tener competencia también para establecer normas generales que no tendrán el nombre de "leyes", pero que lo serán, en el fondo, desde el momento en que habrán sido establecidas por un cuerpo colegial representativo, por un consejo municipal o un ayuntamiento elegido por los vecinos del municipio» ${ }^{27}$. Incluso, con relación a

${ }^{25}$ Esta identificación está presente en algunas de las definiciones clásicas de la «autonomía». Así, por ejemplo, la realizada por SANTI RoMANO: «En el significado más amplio y genérico, indica toda posibilidad de autodeterminación y, por tanto, las capacidades activas, los poderes, los derechos subjetivos. En su significación más específica, que corresponde a su etimología y es la que aquí nos interesa, indica subjetivamente la potestad de darse un ordenamiento jurídico que individuos o Entidades se constituyen por sí, en contraposición al carácter de los Ordenamientos que para ellos son constituidos por otros». Fragmentos de un diccionario jurídico. Buenos Aires, 1964, p. 38. O también la de GianNinI, según el cual por autonomía debemos entender la «potestad atribuida en los ordenamientos jurídicos estatales a entes diversos del Estado de emanar normas constitutivas del mismo Ordenamiento jurídico estatal». «Autonomía», Rivista Trimestrale di Diritto Pubblico. N ${ }^{\circ} 4,1951$, p. 856. Sobre el concepto de «autonomía» véase el primer capítulo del libro de Alfredo Galán Galán, La potestad normativa autónoma local. Atelier. Barcelona, 2001, pp. 41 ss.

${ }^{26}$ García Roca es contundente al respecto: «la autonomía de los entes locales, pese a no venir dotados de una potestad legislativa, es — a mi juicio — una "autonomía política" y no meramente "administrativa", como hasta hoy se ha venido manteniendo por la jurisprudencia y la mayoría de la doctrina, puesto que realmente permite, de un lado, elaborar una dirección política propia y potencialmente divergente de otras y, de otro, excluir tutelas políticas. Durante los años ochenta y noventa, la doctrina española, acaso por influencia de la doctrina regionalista italiana, ha confundido las ideas de "autonomía legislativa" y "autonomía política", dos manifestaciones de un mismo fenómeno, la "autonomía territorial", que pueden coincidir, pero no necesariamente deben hacerlo. Son conceptualmente cosas distintas. Sin negar la obvia importancia de la potestad legislativa, cabe perfectamente una elaboración de "políticas" propias en el ámbito local mediante el ejercicio de unas facultades de ejecución, de Administración y gestión, y de gasto verdaderamente autónomas, en cuanto no sometidas a más controles que los estrictamente judiciales.» Además, señala GARCía Roca que «tampoco puede olvidarse la singularidad como fuente del Derecho de la potestad normativa local. La relaciones de complementariedad y ejecución entre la potestad reglamentaria del Gobierno y la potestad legislativa del Parlamento, ambas fuentes de órganos ubicados dentro de un mismo ente territorial (el Estado o la CA), y copartícipes de una misma dirección política, o el intenso alcance vinculatorio del principio de legalidad, no pueden predicarse con idéntico tenor de las relaciones entre potestad legislativa estatal o autonómica y la potestad reglamentaria de unas entidades locales dotadas de autonomía política. La vieja y consolidada doctrina constitucional que acantona la autonomía local como autonomía meramente administrativa, por varias razones, estimo que debería ser revisada a la luz que proyecta la nueva acción y desde una consideración más realista». J. García Roca, «El nuevo conflicto en defensa de la autonomía local», Justicia Administrativa. $\mathrm{N}^{\circ}$ extraordinario, 2000, sobre «La reforma del régimen local», p. 12. 
la potestad normativa local, se ha llegado a afirmar que «el poder local es un poder normativo autónomo, que se fundamenta por ello directamente en la Constitución y respecto del cual la ley juega sólo como límite o marco. Por decirlo gráficamente y sin rigor técnico: la Ordenanza es la ley en la economía interna del ordenamiento local» ${ }^{28}$. Es decir, los entes locales también dictan normas primarias, aunque no se denominen «leyes» ${ }^{29}$, en cuanto han sido establecidas por un órgano representativo elegido por los vecinos del municipio ${ }^{30}$.

En todo caso, la consecuencia más relevante de la configuración de la autonomía local como «autonomía en el marco de la ley» ${ }^{31}$ no es la negación de una capacidad creativa propia, sino más bien la reducción de su ámbito competencial y, por tanto, de su ámbito de actuación políti$\mathrm{ca}^{32}$. Lo que no cabe es negar que, dentro de ese margen señalado por el

27 Hans Kelsen, Teoría general del Estado. Ed. Nacional. México, 1979, p. 240. En todo caso, debemos recordar que para KeLSEN los municipios ejercen dominio y realizan actos de coacción, no por derecho propio, sino por concesión del Estado. La comunidad local estaría constituida por un orden válido para todo el territorio estando el fundamento de esa validez en el orden central. El municipio sería un órgano del Estado que existe en virtud de una delegación estatal. Ibidem, pp. 154-6, 240-2.

28 L. Parejo Alfonso, «La autonomía local en la Constitución», cit., p. 40. En otra de sus obras había afirmado que «La potestad local es discrecional obviamente, pero su discrecionalidad no es sin más la ordinaria de las potestades administrativas de este carácter, es decir, la que opera no tanto sobre el supuesto de hecho, cuanto más bien sobre la consecuencia legal. Se trata de una discrecionalidad semejante en su sustancia (que no en su alcance, indudablemente menor por razones obvias) y salvando las distancias, a la plenamente política de que goza el Parlamento a la hora de toma de decisión formalizada en la Ley. Es ésta una afirmación que nada nuevo descubre y que no debe sorprender». Administrar y juzgar: dos funciones constitucionalmente distintas y complementarias. Tecnos. Madrid, 1993, p. 93.

29 Joaquín García Morillo, La configuración constitucional..., cit., p. 49. García Roca afirma en este sentido que la ordenanza local se aprueba hasta cierto punto con la "forma de ley" — discusión, publicidad y representación - típica de un órgano deliberante. «El concepto actual de autonomía local...», cit., p. 59. Sobre esta equiparación, véase L. PAREJO Alfonso, La potestad normativa local. Marcial Pons. Diputación de Barcelona, 1998, pp. 67-82. Sobre la singularidad de la Administración Local desde el punto de vista de la legitimidad democrática, véase Alfredo GALÁN, La potestad normativa autónoma local, cit, pp. 198 ss.

30 En este sentido es necesario replantear la misma concepción tradicional de la «reserva de ley» desde la óptica de la estructura territorial del Estado para evitar la desnaturalización de las autonomías territoriales. L. PARejo Alfonso, Derecho básico de la Administración Local, cit., p. 128. Sobre la necesidad de modular la «reserva de ley» en relación a la potestad normativa de los entes locales, véanse Alfredo Galán, La potestad normativa autónoma local, cit., pp. 230 ss.; y José Luis Blasco Díaz, Ordenanza municipal y ley. Marcial Pons. Madrid, 2001, pp. 129 ss.

31 J. García Morillo, La configuración constitucional de la autonomía local, cit., p. 30. L. PAREJo Alfonso, «La autonomía local en la Constitución», cit., p. 55; y en «La autonomía local. Contenido constitucional y configuración legal básica», Cuadernos de Derecho Judicial. Administración Autonómica. CGPJ. Madrid, 1992, p. 207. 
legislador, existe espacio para gestionar los intereses locales de acuerdo con un determinado programa político. Es decir, existen, y en todo caso deben garantizarse, determinados espacios de discrecionalidad política ${ }^{33}$.

Por lo tanto, el ordenamiento local conjuga su delimitación por la ley con su capacidad creativa, conectada ésta con la definición de los intereses y necesidades del municipio y con la articulación de los medios para satisfacerlos. Incluso el Tribunal Supremo ha llegado a afirmar que el Reglamento local tiene facultades de innovación normativa, en el sentido de que «puede añadir reglas en el sentido de aclarar, desarrollar y concretar los preceptos legales, dictar normas de procedimiento, y regular la organización, cuestiones todas ellas que forman parte del contenido de los Reglamentos, e indirectamente inciden en los derechos y deberes de los ciudadanos, lo que pueden hacer, incluso, condicionándolos». Es decir, el Reglamento local «no puede contener mandatos nuevos respecto a la Ley pero sí debe comprender la reglas precisas que aseguren la correcta práctica de la ley» (STS de 10 de julio de 1992).

Pero, además, la actividad política institucionalizada no sólo se expresa a través del ejercicio de la función legislativa: «Lo esencial es la correspondencia entre la voluntad colectiva de una comunidad identificada por el dato básico de su convivencia en un mismo territorio, es decir, la de los ciudadanos que la componen en cuanto tales, y la acción pública de las organizaciones representativas de los mismos que tienen encomendada la gestión de una parte de sus intereses» ${ }^{34}$ Es decir, la caracterización de la autonomía no ha de situarse tanto en la potestad de darse normas sino más bien en la gestión de los asuntos comunes de una determinada colectividad, bajo la propia responsabilidad y, por lo tanto, sin sujeción a las directrices y principios de Administraciones superiores ${ }^{35}$. Es decir, tal y como ha recordado el TC, «el legislador tiene vedada toda regulación de la capacidad decisoria de los entes locales respecto de las materias de su interés que se sitúe por debajo de ese umbral mínimo que les garantiza su participación efectiva en los asuntos que les atañen y, por consiguiente, su exis-

\footnotetext{
32 «Lo que sitúa a los entes locales ante grandes dificultades para ejercer sus competencias no es la ausencia de capacidad para dictar normas de determinado rango, sino la exigencia de que no pocos campos materiales hayan de ser regulados, precisamente, por normas con ese rango». J. García Morillo, La configuración constitucional de la autonomía local, cit., p. 31.

33 Joan BARATA I Mir, Los actos de gobierno en el ámbito municipal. Tecnos. Madrid, 1999, pp. $75-76$.

34 Miguel Sánchez Morón, La autonomía local, cit., p. 175.

35 F. Sosa WAGNER, «Los principios del nuevo régimen local», Tratado de Derecho Municipal, cit., p. 195.
} 
tencia como reales instituciones de autogobierno» (STC 159/2001, de 5 de julio).

Así, el carácter político de la autonomía local viene marcado, en primer lugar, porque a través de los entes locales se expresa el valor «pluralismo político» ${ }^{36}$. La autonomía consiste «en que las Corporaciones locales puedan intervenir en cuantos asuntos les afecten de tal forma y manera que dispongan siempre de un ámbito de decisión política de la entidad suficiente como para poder ofrecer, frente a los ciudadanos, unas señas políticas de identidad que permitan a éstos reconocer el contenido de la oferta que les motivó a mandatar a unos determinados representantes, formando con sus votos una mayoría, en lugar de a otros» ${ }^{37}$.

En definitiva, el carácter político de la autonomía local deriva de la clara conexión entre los principios de autonomía y democrático ${ }^{38}$, los cuales han de entenderse como «principios constitucionales de un todo» ${ }^{39}$. El propio TC ha reconocido esa vinculación en sentencias como la 33/1993:

36 M. SÁnchez Morón, La autonomía local, cit., p. 32. Como señala PAREJo, «en su vertiente territorial...el pluralismo político conecta con el principio de autonomía, toda vez que ésta asegura justamente la efectividad de dicho pluralismo». «La autonomía local», Revista de Estudios de la Administración Local y Autonómica. $\mathrm{N}^{\circ} 229,1986$, p. 25. En el mismo sentido, LeguiNA considera que «la interdependencia entre pluralismo político y autonomía de los municipios se traduciría así en el establecimiento de unos límites al legislador que garanticen la existencia de un espacio de actuación dentro del cual tengan cabida y puedan plantearse libremente las distintas opciones políticas, todas ellas igualmente válidas dentro de un sistema democrático abierto y plural, asegurándose de tal modo la alternancia espacial del poder político y administrativo, que vendría a completar el tradicional principio constitucional de la alternancia en el tiempo». Jesús LEGUINA, «Gobierno municipal y Estado democrático», Revista de Administración Pública. N 100-102, 1983, p. 2192; y Escritos sobre autonomías territoriales, cit., p. 264.

37 F. Sosa Wagner, «La autonomía local», cit., p. 3218. De acuerdo con este planteamiento, y como señalara GARcía MoriLlo, «la negación del carácter político es harto complicada». La configuración constitucional de la autonomía local, cit., p. 28.

38 La autonomía municipal, legitimada por la democracia, manifiesta una suerte de división territorial o vertical del poder y precisamente «por su carácter de divisor del poder y controlador del mismo, la autonomía municipal es un fundamento esencial del orden libre de la democracia». Klaus Stern, El derecho del Estado de la República Federal Alemana. C.E.C. Madrid, 1987, p. 703.

Sobre esa conexión, véase por ejemplo José Luis CARRO, «El debate sobre la autonomía municipal», Revista de Administración Pública. N 147, 1998, p. 61; F. Sosa WAGNER, «La autonomía local», cit., p. 3209; D. LoperenA Rota, «El Pleno del Ayuntamiento», Documentación Administrativa, No 228, octubre-diciembre 1991, p. 82.

39 Francisco Sosa Wagner, Manual de Derecho Local. Aranzadi. Pamplona, 2000, p. 49. En un sentido similar, Luis Morell considera que «el concepto de autonomía local que se deriva de nuestra Constitución debe asociarse con dos notas fundamentales: el autogobierno democrático, es decir, la plena representatividad de la colectividad local, y la posibilidad de ejercer sus competencias bajo su propia responsabilidad, sin tutelas ni injerencias externas». «La Administración Local 
«es evidente que uno de los aspectos esenciales del modelo de autonomía local garantizado en todo el Estado atañe al funcionamiento democrático de los órganos de gobierno de las Corporaciones Locales y, dentro de él, en concreto, a lo que afecta al quórum de mayorías necesarias para la adopción de los acuerdos de los órganos colegiados superiores, ya que los preceptos relativos a estas cuestiones definen precisamente un modelo de democracia local».

Esta conexión se establece con rotundidad en los dos apartados del artículo 3 de la Carta Europea de Autonomía Local. El primer apartado, como ya hemos visto, define la autonomía local como «el derecho y la capacidad efectiva de las Entidades locales de ordenar y gestionar una parte importante de los asuntos públicos, en el marco de la ley, bajo su propia responsabilidad y en beneficio de sus habitantes». El apartado segundo establece que este derecho «se ejerce por Asambleas o consejos integrados por miembros elegidos por sufragio libre, secreto, igual, directo y universal y que pueden disponer de órganos ejecutivos responsables ante ellos mismos».

Esa expresión del pluralismo se concreta en la configuración de un ente legitimado democráticamente, con capacidad para adoptar decisiones propias e independientes con respecto a otros entes de categoría superior, así como para ejecutarlas. A través de la decisión del cuerpo electoral, que da contenido a unos órganos de carácter representativo que asumen el gobierno y la administración de los municipios, las entidades locales «deducen su indirizzo político-administrativo no del Estado, sino de sus propias comunidades, es decir, de la mayoría de su propia comunidad» ${ }^{40}$. Además, no podemos olvidar que el municipio constituye el espacio natural de la vida cotidiana del ciudadano y, por tanto, el ámbito donde ejerce la mayor parte de sus derechos y libertades y sobre los que necesariamente inciden las políticas locales.

en la Constitución», cit., p. 835. O, como ha señalado José Manuel BANDRÉs, los Ayuntamientos se configuran en nuestra Constitución como democráticos «por ser expresión de una de las proyecciones del principio de división de poderes que se manifiesta en la distribución vertical del poder y permitir articular la organización territorial del Estado, por advertirse como gobiernos responsables, representativos de la colectividad local, como cauce de participación política de los ciudadanos en los asuntos públicos y por su vinculación a los derechos fundamentales». «El valor del principio de democracia local en la jurisprudencia contencioso-administrativa de los Tribunales Superiores de Justicia», Anuario de Gobierno Local, 1998, p. 323.

40 M. S. Giannini, «Autonomia pubblica», Enciclopedia del Diritto, IV. Giuffrè. Milán, 1964, pp. 356-366. 
Por lo tanto, la nota esencial que define el carácter «político» de la autonomía es, de una parte, el carácter representativo de las colectividades locales, y de otra, la acción de los órganos representativos de los ciudadanos del municipio que tienen encomendada la gestión de una parte de sus intereses ${ }^{41}$. En palabras de Dilys M. HILl, «el gobierno local es "político", en el sentido más amplio del término, porque en él se plantean cuestiones y políticas de actuación que constituyen, propiamente, los temas de discusión, debate y oposición de intereses y puntos de vista» ${ }^{42}$.

Los órganos representativos locales tienen, pues, capacidad creativa, pueden formular sus propias políticas, las cuales concretan en decisiones que, en todo caso, tendrán como límite la Constitución y la ley ordinaria ${ }^{43}$. SOSA WaGner lo ha explicado con claridad: «Si establecido está, como hemos visto, que los órganos de las Corporaciones locales se integran mediante elecciones a las que concurren ofertas políticas variadas, entre las que los ciudadanos eligen, es para que luego se perciba, en el gobierno de la ciudad (un banco de pruebas de primer orden), la forma en que se plasma la acción de quienes, por la mayoría alcanzada, han conseguido el poder... Cuando este dato se olvida o simplemente se le relega, estamos escamoteando el significado último de la creación de unas organizaciones

41 «La representatividad de los entes locales es representatividad política...» M. SÁNCHEZ MoRóN, La autonomía local, cit., p. 175. Incluso deberíamos recordar que la tesis del barón Vom Und Zum STEIN se basa en que la autonomía municipal vendría a ser un eficaz remedio contra la burocratización en la gestión de los intereses propios de la comunidad vecinal mediante la participación de los ciudadanos en el ámbito donde se desarrollaba su vida cotidiana. Véase al respecto José Luis CARRo, «El debate sobre la autonomía municipal», cit., p. 68. Luis AgUiAR DE LuQUE considera, en el mismo sentido, que la principal razón de ser de la autonomía local es su contribución a la realización del principio democrático que consagra el art. $1 \mathrm{CE}$, siendo cauce institucional de materialización del derecho de participación política. «Comunicación» en J. García Morillo, La configuración constitucional..., cit., pp. 100-101.

42 Dilys M. HiLl, Teoría democrática y régimen local, Instituto de Estudios de Administración Local, Madrid, 1980, p. 99. En este sentido, más adelante afirma que «las unidades locales son, en efecto, órganos de gobierno, y no meras oficinas o instancias administrativas para la gestión de los diferentes servicios», ibidem, p. 347.

43 L. PARejo AlFonso, «El régimen jurídico de la Administración local, hoy», en La posición institucional de la Administración local ante el siglo XXI. IVAP. Bilbao, 1998, p. 29. El mismo autor había definido con anterioridad el «autogobierno» como «capacidad de formulación y desarrollo de una política, una estrategia de servicio público propio...» Derecho básico de la Administración Local, cit., p. 159. En el mismo sentido, Ramón MARTín MATEO, cuando afirma que «es imposible aislar una aséptica función ejecutiva neutralmente aplicadora de la ley. Las Corporaciones locales hacen, desde luego, política, en el sentido incluso ideológico del término, en cuanto que toman decisiones sobre la base de consideraciones axiológicas, si bien es cierto que el margen de decisión es frecuentemente constreñido». «Administración local y Constitución», REALA, $\mathrm{N}^{\circ} 225$, enero-marzo 1985, p. 16. Véase también Carlos R. Alba y Francisco J. Vanaclocha, El sistema político local. Un nuevo escenario de gobierno, cit., p. 10. 
públicas según el principio democrático... Si las leyes no dejan el suficiente espacio a las Corporaciones locales para que éstas puedan hacer opciones políticas (y no simplemente administrar), es mejor modificar el modelo mismo, suprimir el carácter democrático de las Corporaciones y confiar los servicios a organizaciones especializadas» ${ }^{44}$.

La autonomía política supone, pues, la existencia de un margen de libertad, constitucionalmente garantizada, para que el ente local decida cómo gestiona «sus intereses» sin que en esa capacidad pueda ser suplantado o sustituido por otras administraciones públicas ${ }^{45}$. El artículo 11 LRBRL lo expresa con rotundidad al reconocerle al municipio «plena capacidad para el cumplimiento de sus fines».

La autonomía local vendría así definida por la «capacidad de dirección (indirizzo) política-administrativa de sus titulares, en el ejercicio de las competencias propias de los entes locales», siguiendo el concepto de autonomía política dado por Massimo Severo Giannini y que marcaría la orientación que prevaleció en la doctrina italiana. Según este autor, la autonomía política debe entenderse como la capacidad del ente autónomo de orientar y dirigir, política y administrativamente, la comunidad (potestà propria di indirizzo político-amministrativo). Esta potestad deriva no del Estado sino de la propia comunidad. Esto es lo que hace que los entes locales tengan una posición específica respecto de cualquier ente público ${ }^{46}$.

Existe, por tanto, una acción de gobierno o una función de dirección política local. La capacidad de «dirección política» se halla implícita en

\footnotetext{
44 F. Sosa Wagner, Manual de Derecho Local, cit., p. 47

45 «El concepto de autonomía local que se deriva de nuestra Constitución debe asociarse con dos notas fundamentales: el autogobierno democrático, es decir, la plena representatividad de la colectividad local, la posibilidad de ejercer sus competencias bajo su propia responsabilidad sin tutelas ni injerencias externas». Álvaro DE LA CRUZ GIL, «La garantía de la autonomía local», Administraciones Públicas y Constitución, cit., p. 835. Véanse las reflexiones que al respecto realiza Luis ORTEGA en El régimen constitucional de las competencias locales. I.N.A.P. Madrid, 1988, pp. 21 ss.
}

46 M. SÁnchez Morón, La autonomía local, cit., p. 176. Incluso, como había señalado con anterioridad este mismo autor, los órganos locales pueden adoptar criterios de gestión distintos y aun opuestos a los del Gobierno y Administración estatales. M. SÁnChez Morón, «Notas sobre la función administrativa en la Constitución española de 1978», en Alberto PrEDIERI y Eduardo García DE EnTERría, La Constitución Española. Estudio sistemático. Civitas. Madrid, 1980, pp. 624-664.

La definición de M.S. Giannins puede verse en Diritto Amministrativo. Giuffrè. Milán, 1970. Vol. I, pp. 288-291. Del mismo autor, véanse «Autonomia. Teoria generale e diritto pubblico», cit, pp. 356-366; y sus Istituzioni di Diritto Amministrativo. Giuffrè. Milano, 1981, pp. 207-208. 
la atribución del gobierno y la administración que el artículo 140 CE realiza a los Ayuntamientos, así como el artículo 141 a las Diputaciones. Atribución difícil de precisar por la escasa nitidez que presentan los perfiles de las funciones de «gobierno» y «administración» ${ }^{47}$. Entre ambas existe un continuum unitario ${ }^{48}$ : «la política pública... es un proceso continuo, cuya formulación resulta inseparable de su ejecución. La política pública se está formando a medida que se va ejecutando, y se ejecuta a medida que se establece. La política, como la administración, juega un papel continuado lo mismo en el renglón de la formación que en el de la ejecución» ${ }^{49}$.

Pero, además, esa capacidad de «dirección política» se desprende con claridad del dictado del artículo 25 LRBRL: «el municipio para la gestión de sus intereses y en el ámbito de sus competencias puede promover toda clase de actividades y prestar cuantos servicios públicos contribuyan a

47 Como ha señalado Francesco Merloni, más bien hay que hablar de una necesaria coexistencia en el seno de las Administraciones públicas entre órganos de gobierno y dirección, compuestos como norma por representantes electivos, pertenecientes a la clase política, al sistema de partidos... y titulares de los oficios administrativos, elegidos como norma entre funcionarios profesionales. En términos sociológicos, se podría hablar de una cohabitación necesaria, cuando no de conflicto, entre "políticos" y "burócratas" en la misma realidad operativa». Incluso llega a afirmar que «la condición principal para el buen éxito de la distinción entre dirección/gestión radica en el reforzamiento contextual de ambos polos, de ambas categorías, titulares de poderes citados». Y cita para corroborar su afirmación un fragmento de las «Directrices para la modernización de las Administraciones públicas», elaborado en Italia por el Departamento para la Función Pública en 1993: «Cada Administración es el producto de la interacción entre (...) los cuerpos políticos destinados a la dirección de los aparatos y cuerpos profesionales llamados a ejecutar los impulsos políticos (...) no es sólo de la bondad de un diseño, sino también de las fuerzas y de los conflictos que él genera o de aquellos que alimenta, de los que depende el buen éxito de un intento de modernización». «La distinción entre "política" y "administración"», Documentación Administrativa. $\mathrm{N}^{\circ}$ 250-251, enero-agosto 1998, pp. 54-55, 62. Sobre este tema, véase Ana María NiETo-GuERrERo Lozano, Los entes locales municipales. Entre la política y la administración, I.N.A.P. Madrid, 2001.

48 L.M DíEz-PICAZo, «La estructura del Gobierno en el Derecho español», Documentación Administrativa. $\mathrm{N}^{\circ} 215,1988$, p. 41. En un sentido similar, véanse L. PAREJo Alfonso, «Los principios del nuevo régimen local», cit., p. 106; Luis Morell OCAÑA, El régimen local español, cit., p. 47; J. GARCía RocA, «El concepto actual de autonomía local...», cit., p. 52.

49 Carl J. Friedrich, Gobierno constitucional y democracia. Instituto de Estudios Políticos. Madrid, 1975, p. 230. En Italia el Decreto legislativo n $29 / 1993$ introdujo por vez primera mediante una norma general relativa a todas las Administraciones Públicas el principio de la necesaria distinción entre «política» y «administración»: «Los órganos de gobierno definen los objetivos y los programas de actuación y comprueban la adecuación de los resultados de la gestión a las directrices generales impartidas», «A los dirigentes administrativos compete la gestión financiera, técnica y administrativa, comprendida la adopción de todos los actos que vinculan a la Administración hacia el exterior, mediante poderes autónomos de gasto, de organización de los recursos y materiales, y de control. Son los responsables de la gestión y de los correspondientes resultados». Citado por F. MERLONI en «La distinción entre “política” y “administración”...», cit., pp. 35-36. 
satisfacer las necesidades y aspiraciones de la comunidad vecinal». El legislador, por lo tanto, deberá articular un margen de actuación que permita que cada corporación adopte, dentro del marco establecido por el ordenamiento, decisiones políticas, emanadas de órganos democráticos representativos, y que suponen una opción en cuanto la tutela de los intereses municipales ${ }^{50}$. La autonomía de los entes locales se traduce así en «la capacidad para decidir libremente entre varias opciones legalmente posibles, de acuerdo con un criterio de naturaleza esencialmente política» (STC 193/87, de 9 de diciembre).

En definitiva, no cabe ninguna duda de que el municipio, a través de su Ayuntamiento, utiliza técnicas de gobierno en la gestión de sus intereses de acuerdo con la atribución que le otorga el artículo 140 CE, las cuales suponen un margen de discrecionalidad política y que, por tanto, no se hallan sujetas a controles de oportunidad. Y ello aunque la nueva Ley de Jurisdicción Contencioso-Administrativa, la Ley 29/1998, al precisar determinadas actividades de gobierno no sujetas al Derecho administrativo no se refiera a los gobiernos locales. Su artículo 2.a) sólo alude a una actividad de los Gobiernos estatal y autonómicos, que no encaja en la contemplada en el artículo 1 y que, por tanto, no está sujeta al Derecho administrativo, aunque es susceptible de control jurisdiccional en determinados aspectos (afectación de derechos fundamentales, elementos reglados, indemnizaciones). De esta regulación podría deducirse que los entes locales no desarrollan una actividad de carácter político, conclusión errónea de acuerdo con todo lo dicho anteriormente. Baste con citar, como ejemplos, el carácter innegablemente político del planteamiento de una moción de censura al alcalde, de la decisión del Pleno de un Ayuntamiento de plantear un conflicto en defensa de la autonomía local o la declaración de aquél relativa a cualquier cuestión de política, municipal o no ${ }^{51}$.

\footnotetext{
50 Joan BARATA I Mir, Los actos de gobierno en el ámbito municipal, cit., pp. 72-73.

51 Joan BARATA I MIR analiza diversos ámbitos susceptibles de constituir una actividad municipal de gobierno stricto sensu, tales como las declaraciones políticas realizadas por el Pleno. Tras analizar varios ejemplos, llega a la siguiente conclusión: «por parte de los órganos municipales de gobierno se puede manifestar una determinada posición política en cuanto tal, relativa a tales cuestiones, y, por lo acabado de señalar, desvinculada de la pretensión jurídica de ejercicio de potestad alguna. Incluso, afinando más el razonamiento, tales acuerdos podrían llegar a ser considerados, además de en tanto que posicionamiento político de los órganos municipales de gobierno, como vía para hacer llegar al órgano capacitado para adoptar acuerdos jurídicamente vinculantes con relación a la materia correspondiente, la petición efectuada al respecto por parte de lo que no es otra cosa que un determinado colegio de legítimos representantes democráticos de una facción de la colectividad». Los actos de gobierno en el ámbito municipal, cit., pp. 104-105.
} 


\section{LA PREVISIÓN DE CONTROLES DE «LEGALIDAD» PERO NO DE «OPORTUNIDAD»}

La capacidad de indirizzo de los entes locales excluye, pues, la dependencia jerárquica y cualquier control de oportunidad política sobre la voluntad expresada por las corporaciones locales. La base representativa democrática del municipio implica la responsabilidad política del Ayuntamiento ante los electores, no ante el Gobierno del Estado ni ante ningún órgano de las $\mathrm{CCAA}^{52}$. Este principio queda también claro, como hemos visto, en el artículo 3 CEAL, el cual al definir la autonomía local, dispone que «el derecho y la capacidad efectiva de las Entidades locales de ordenar y gestionar una parte importante de los asuntos públicos, en el marco de la ley, bajo su propia responsabilidad y en beneficio de sus habitantes».

Sólo cabrían, pues, controles de legalidad, pues autonomía no significa exención de la sujeción al ordenamiento jurídico ${ }^{53}$, tal y como además expresa el artículo 8.2 de la Carta Europea de Autonomía Local. El TC se pronunció tajantemente al respecto en su sentencia 4/81, excluyendo los «controles genéricos e indeterminados que sitúen a las entidades locales

\footnotetext{
52 El municipio dispone de «un poder para fijar unas orientaciones de carácter político, social, económico y cultural eligiéndolas entre varias posibles, de acuerdo con la específica responsabilidad contraída ante el cuerpo electoral, dando prioridad a unos intereses y relegando a otros, de acuerdo con una estrategia gradual que va seleccionando los niveles de actuación. No hay que olvidar que ese indirizzo se desarrolla en un ámbito territorial limitado que no se desvincula, además, de las orientaciones políticas y macroeconómicas que fijan los restantes órganos del Estado (Legislativo, Gobierno, CCAA), puesto que el municipio no es un ente soberano, pero ese marco no resta intensidad a la técnica de un gobierno municipal.» J. GARCíA FernándeZ, La autonomía del Derecho político municipal...., cit., pp. 1404 y 1423. En el mismo sentido, Ramón MARTín MATEO cuando habla de la «autorresponsabilidad» como una de las características de las corporaciones locales. «Administración local y Constitución», cit., p. 30. Véase también J. García Roca, «El concepto actual de autonomía local...», cit., p. 55. Sobre el tema de los controles sobre las corporaciones locales véase A. FANLO, Fundamentos constitucionales de la autonomía local, cit., p. 55.

53 Parejo Alfonso hace al respecto unas afirmaciones cuando menos de dudosa interpretación: «En nuestro Derecho nada en la norma constitucional apoya la supuesta incompatibilidad entre autonomía garantizada y control administrativo. Antes al contrario y para el caso de la autonomía local, el encuadramiento total de ésta en la Ley ordinaria avala más bien, a la luz del Derecho comparado, la conclusión inversa. La gestión de los intereses de las instancias locales en que consiste la autonomía local y, por tanto, el ejercicio por dichas instancias de las competencias que tengan atribuidas es siempre, por definición, ejecución de Leyes y, por tanto, normas heterónomas. Consecuentemente, y también por definición, existe siempre un interés de las instancias legisladoras, es decir, definidoras del marco legal de aquella autonomía tanto en la observancia por ésta de los límites de dicho marco como en el resultado mismo de la acción de la instancia autónoma». Derecho básico de la Administración local, cit., p. 153. Ahora bien, el propio autor, más adelante, señala que la capacidad de autoorganización, en cuanto parte integrante de la autonomía local, «ha de ser especialmente refractaria a ser objeto de técnicas o instrumentos de control». Ibidem, p. 159.
} 
en una posición de subordinación o dependencia casi jerárquica respecto de la administración estatal o autonómica». Además, en la sentencia 27/87 dejó claro que la utilización de técnicas de coordinación «no puede traducirse en la emanación de órdenes concretas que prefiguran exhaustivamente el contenido de la actividad del ente coordinado, agotando su propio ámbito de decisión autónomo: en cualquier caso, los medios y técnicas de coordinación deben respetar un margen de libre decisión o de discrecionalidad a favor de las administraciones sujetas a la misma, sin el cual no puede existir verdadera autonomía» ${ }^{54}$.

En este sentido hay que entender los «controles» que la propia LRBRL prevé en el capítulo III de su Título V dedicado a la «Impugnación de actos y acuerdos y ejercicio de acciones» ${ }^{55}$. En él se prevé que, junto a los sujetos legitimados en el régimen general del proceso contenciosoadministrativo, la Administración del Estado y la de las CCAA podrán impugnar los actos y acuerdos de las Entidades locales que incurran en infracción del ordenamiento jurídico (artículo 63). En este caso, dichas Administraciones podrán requerir a la entidad local para que anule el acto o acuerdo en el plazo de un mes, petición que habrá de ser motivada y que deberá expresar la normativa que se estime vulnerada. Ahora bien, el acto o acuerdo podrá impugnarse directamente sin necesidad de formular dicho requerimiento (artículo 65) ${ }^{56}$. Además, si una entidad local adoptara actos o acuerdos que atentaran gravemente contra el interés general de

\footnotetext{
${ }^{54}$ El art. 59 LRBRL prevé las posibilidades de planificación por parte del Gobierno de la Nación o del Consejo de Gobierno de las CCAA, con la finalidad de «asegurar la coherencia de la actuación de las Administraciones públicas, en los supuestos previstos en el número 2 del art. 10» y en el caso de que la colaboración prevista en los artículos 57 y 58 no pudiera alcanzarse o fuera inadecuada por razón de las características de la tarea pública de que se trate. En este caso, la ley exige que la coordinación se realice «mediante la definición concreta y en relación con una materia, servicio o competencia determinados de los intereses generales o comunitarios, a través de planes sectoriales para la fijación de los objetivos y la determinación».

55 Como bien ha recordado Rafael PizArRo, «la LRBRL optó decididamente por un grado superior de autonomía de municipios, provincias e islas que casi no admite ni siquiera los controles de legalidad sino que, por el contrario, obliga como regla general a las Administraciones estatal y autonómica que estimen que un acuerdo legal es ilegal a impugnarlo ante la jurisdicción contencioso-administrativa. Es decir, la LRBRL dio, en este aspecto de la libre administración de municipios, provincias e islas, un grado de autonomía muy superior al que imponía la Constitución y al que garantiza la Carta Europea de Autonomía Local». Las entidades de ámbito territorial inferior al municipio. CEMCI. Granada, 2002, p. 202.

${ }^{56}$ En estos supuestos no se establece «un control genérico de legalidad, ni un control específico de las Comunidades Autónomas sobre los actos y acuerdos de las Corporaciones locales, sino sólo la posibilidad de someterlos a revisión jurisdiccional mediante procedimientos singulares que contemplan una fase previa de rectificación de ilegalidades que quedan en manos de la correspondiente entidad local. Pero el control de legalidad no lo llevan a cabo las Administraciones estatal o autonómica, sino los órganos jurisdiccionales contencioso-administrativo (STS 13 de marzo de
} 
España, el Delegado del Gobierno, previo requerimiento para su anulación al Presidente de la Corporación efectuado dentro de los diez días siguientes al de la recepción de aquellos, podrá suspenderlos y adoptar las medidas pertinentes para la protección de dicho interés. Acordada dicha suspensión, el Delegado del Gobierno deberá impugnarlo en el plazo de 10 días desde la suspensión ante la jurisdicción contencioso-administrativa (artículo 67) ${ }^{57}$.

Por otra parte, el artículo 56.1 LRBRL establece el deber de información de las Corporaciones locales a las Administraciones superiores, lo cual es indicativo del menor grado de autonomía de que disponen aquéllas. En concreto, el artículo prescribe que «las Entidades locales tienen el deber de remitir a las Administraciones del Estado y de las CCAA, en los plazos y forma que reglamentariamente se determinen, copia, o en su caso, extracto comprensivo de los actos y acuerdos de las mismas. Los Presidentes y, de forma inmediata, los Secretarios de las Corporaciones serán responsables del cumplimiento de este deber.» Además, con respecto a la aplicación de la legislación estatal y autonómica, la LRBRL faculta a la Administración del Estado y de las CCAA para comprobar la efectividad de la aplicación de aquélla y para recabar y obtener información concreta sobre la actividad municipal, pudiendo solicitar incluso la exhibición de expedientes y la emisión de informes (artículo 56.2 LRBRL). Igualmente se prevé que tanto la Administración del Estado como la de las CCAA faciliten el acceso de los representantes legales de las Entidades locales a los instrumentos de planificación, programación y gestión de obras y servicios que les afecten directamente (artículo 56.3 LRBRL).

1999)». F.J. Marcos Oyarzun, Nuevo escenario de poderes en la Administración Local Municipal. Aranzadi. Pamplona, 2000, p. 153.

${ }^{57}$ El TC, en su sentencia 11/99, de 11 de febrero, dejó claro que «ejercitada por el legislador estatal la opción política a favor de una regulación claramente favorable a la autonomía en materia de suspensión de acuerdos, la norma correspondiente ha de calificarse de básica, también en sentido material por cuanto tiende a asegurar un nivel mínimo de autonomía a todas las Corporaciones locales en todo el territorio nacional, sea cual sea comunidad autónoma en que estén localizadas, lo que resulta plenamente congruente con la garantía institucional del art. $137 \mathrm{CE}$; garantía que opera tanto frente al Estado como frente a los poderes autonómicos.... los arts. 65 y 66 de la LRBRL pueden ser invocados legítimamente no sólo como ejercicio de la competencia normativa básica estatal derivada del art. 149.1.6 y 149.1.8 CE (STC 214/89, FJ 3), sino también como expresión de una legítima opción legislativa estatal ampliadora del ámbito de la autonomía local». En dicha sentencia se alude a todo un conjunto de pronunciamientos, como los de 2 de febrero y 29 de abril de 1981, 28 de junio de 1983, 5 de diciembre de 1984 y 27 de febrero de 1988, en los que el TC fue concretando la compatibilidad entre la autonomía local con las técnicas de control en manos de las Administraciones superiores. Sistematiza esta doctrina L. PAREJo Alfonso en «La autonomía local en la Constitución», cit., pp. 83-84. 
Por su parte, los artículos 60 y 61 LRBRL, junto al ya citado artículo 67, incluido en el capítulo relativo a la impugnación de actos y acuerdos, establecen las medidas más contundentes de control de la Administración del Estado o de la Comunidad Autónoma sobre los entes locales. El artículo 60 prevé un requerimiento previo en el caso de que «una entidad local incumpliera las obligaciones impuestas directamente por la Ley de forma que tal incumplimiento afectara al ejercicio de competencias de la Administración del Estado o de la CA, y cuya cobertura económica estuviere legalmente o presupuestariamente garantizada, según su respectivo ámbito competencial». En ese requerimiento se concederá el plazo que se estime necesario. Si transcurrido dicho plazo, nunca inferior a un mes, el incumplimiento persistiera, se procederá a adoptar las medidas necesarias para el cumplimiento de la obligación.

Finalmente, el artículo 61 prevé la medida más extrema y que es la que ha provocado mi reflexión. En concreto, dicho artículo disponía en su redacción originaria que el Consejo de Ministros, a iniciativa propia y con conocimiento del Consejo de Gobierno de la CA correspondiente o a solicitud de éste y, en todo caso, previo acuerdo favorable del Senado, podría proceder, mediante Real Decreto, a la disolución de los órganos de las Corporaciones locales en el supuesto de gestión gravemente dañosa para los intereses generales que supusiera el incumplimiento de sus obligaciones constitucionales. En este caso, se aplicaría la legislación electoral general para la convocatoria de elecciones parciales y la provisional administración ordinaria de la Corporación ${ }^{58}$.

De esta regulación puede deducirse, pues, la compatibilidad entre la autonomía y determinadas formas de tutela administrativa. Tutela que es

58 Como bien ha señalado Parejo Alfonso, entre estas técnicas no existe una gradación o un condicionamiento recíproco «pero es bien evidente que por la propia naturaleza de los presupuestos en que se fundan responden a una lógica de menor a mayor intensidad de incidencia sobre la Administración local: mientras el de coordinación puede calificarse de instrumento normal u ordinario, los de intervención subjetiva (disolución) y objetiva (sustitución de la actividad local) hacen referencia a situaciones disfuncionales más o menos liminares, imposibles de reconducir en otra forma y representan, así, instrumentos ciertamente excepcionales de control.» En todo caso, los arts. 60, 61 y 67 deben considerarse extraordinarios «en orden al fin del mantenimiento de la coherencia de la Administración pública. Y tiene este carácter porque sólo pueden ser actuados en principio por la Administración del Estado (lo que revela que aluden a disfunciones de extrema gravedad, que ponen en cuestión aspectos básicos de la organización territorial del Estado, diferenciándolos del resto) e implican una intervención directa o bien en la actividad de las Corporaciones (sustituyéndola, incluso, por otra propia de la Administración superior) o bien de estas mismas subjetivamente consideradas» L. PAReJo Alfonso, «La autonomía local en la Constitución», cit., pp. 91 y 94. 
necesario interpretar restrictivamente para que, en ningún caso, vulnere la autonomía de las corporaciones locales ${ }^{59}$.

\section{4. ¿LA DISOLUCIÓN DE LAS CORPORACIONES LOCALES COMO MEDIO DE DEFENSA DEL ESTADO?}

Como he apuntado, el artículo 61 LRBRL contiene la forma de control más extrema sobre las Corporaciones locales. En concreto, dicho artículo dispone lo siguiente:

«El Consejo de Ministros, a iniciativa propia, y con conocimiento del Consejo de Gobierno de la Comunidad Autónoma correspondiente o a solicitud de éste y, en todo caso, previo acuerdo favorable del Senado, podrá proceder, mediante Real Decreto, a la disolución de los órganos de las Corporaciones locales en el supuesto de gestión gravemente dañosa para los intereses generales que suponga el incumplimiento de sus obligaciones constitucionales. Una vez acordada la disolución, será de aplicación la legislación electoral general en relación a la convocatoria de elecciones parciales y a la provisional administración ordinaria de la Corporación.»

De acuerdo con el artículo 183 LOREG, debe procederse a la convocatoria de elecciones parciales para la constitución de una nueva Corporación dentro del plazo de tres meses, salvo que, por la fecha en que ésta debiera constituirse, el mandato de la misma hubiese de resultar inferior a un año. Mientras se constituye la nueva Corporación o expira el mandato de la disuelta, la administración ordinaria de sus asuntos corresponderá a una Comisión Gestora designada por la Diputación Provincial o, en su caso, por el órgano competente de la Comunidad Autónoma correspondiente, cuyo número de miembros no excederá del número legal de miembros de la Corporación. En este caso, ejercerá las funciones de Alcalde o Presidente aquel vocal que resulte elegido por mayoría de votos entre todos los miembros de la Comisión.

La LO 1/2003 para la garantía de la democracia en los Ayuntamientos incluye una nueva redacción de dicho artículo, al que se añade un apartado $2^{\circ}$, de acuerdo con el cual «cuando la disolución se produzca porque los órganos de gobierno de la Corporación Local lleven a cabo alguna de las actuaciones previstas en el artículo 61.2 de la LRBRL, la Diputación Provincial o, en su caso, el órgano competente de la Comunidad Autónoma asumirá directamente tras la disolución la gestión ordinaria de la Corpora-

\footnotetext{
59 Véanse sobre esta cuestión Manuel Rebollo y Rafael Pizarro, «Las Entidades Locales Autónomas», Revista Andaluza de Administración Pública. No 42, abril-mayo-junio 2001, pp. 70-71.
} 
ción hasta la finalización del correspondiente mandato, no pudiendo adoptar acuerdos para los que se requiera una mayoría cualificada».

En su redacción inicial, el artículo 61 LRBRL establecía como único supuesto legitimador de la disolución de la Corporación «una gestión gravemente dañosa para los intereses generales que suponga el incumplimiento de las obligaciones constitucionales». Además de la gran dificultad de fundamentar en la práctica este presupuesto habilitante tan genérico, que en todo caso sería concretable a partir de su dicción final — «incumplimiento de las obligaciones constitucionales»—, es evidente que los supuestos añadidos por la LO 1/2003 difícilmente encajan en él. Piénsese en la propuesta de disolver la Corporación local «por acuerdos de los órganos que dan cobertura o apoyo, expreso o tácito, de forma reiterada y grave, al terrorismo o a quienes participen en su ejecución, lo enaltezcan o lo justifiquen, humillen a las víctimas o a sus familiares». ¿Cómo podría justificarse esa cobertura o apoyo? ¿Habría que establecer un elenco de posibles actos de los ayuntamientos en que se concretara ese apoyo? ¿Cómo probar el apoyo tácito? ¿Sería un apoyo tácito no condenar un acto terrorista? ¿Cómo medir la «gravedad» de ese apoyo? ¿Podría una corporación local adoptar algún acuerdo de «apoyo», por ejemplo, a los presos de ETA? En definitiva, nos volvemos a plantear los mismos interrogantes que ya se plantearon con respecto a la primera redacción del artículo 9 de la LO 6/2002, de 27 de junio, de Partidos Políticos ${ }^{60}$, artículo que, pese a su mejora en la tramitación parlamentaria, sigue manteniendo la conducta del apoyo político tácito al terrorismo como causa de la declaración de ilegalidad de un partido (artículo 9.3.a) ${ }^{61}$.

${ }^{60}$ Véase el completo análisis que de esta ley realiza Roberto L. BLANCo VALDÉs, «La nueva ley de partidos. A propósito de la ilegalización de Basatuna», Claves de razón práctica. № 124, 2002, pp. 23-30.

${ }^{61}$ Debemos recordar que la redacción inicial de la Proposición de Ley presentada por populares y socialistas incluía entre las actuaciones dañosas para el interés general los acuerdos que dieran cobertura o apoyo a quienes «perturben gravemente el funcionamiento democrático de la Corporación». Afortunadamente esta cláusula fue eliminada en su tramitación parlamentaria, pues evidentemente se trataba de una cláusula abierta, que afectaba claramente a la seguridad jurídica, y que sería muy difícil de concretar más allá del incumplimiento de las obligaciones que el legislador establece para los órganos y miembros de la corporación. Una interpretación amplia de dicha previsión habría llevado, por ejemplo, a disolver todas aquellas corporaciones en que los Alcaldes impidieron la celebración de las sesiones en que habría de votarse una moción de censura, situación que fue muy frecuente con anterioridad a la reforma de la LOREG llevada a cabo por la LO 8/1999, como consecuencia del llamado «Pacto Local». Incluso, ¿no llevaría esta previsión, por ejemplo, a disolver aquellas corporaciones en que el Alcalde y la mayoría que lo apoya dificulta la labor de control de las minorías? ¿No podría, incluso, aplicarse en los tan frecuentes casos de transfuguismo de concejales? 
El hecho de que el artículo 61 LRBRL se refiera expresamente al «incumplimiento de obligaciones constitucionales» llevaría a excluir las recomendaciones, desiderata o declaraciones políticas que no se traduzcan en una obligación de hacer o no hacer, o que supongan una diferente orientación política de la Corporación Local y Estado.

Pienso que únicamente cabría la disolución cuando la corporación incumpliera alguna obligación impuesta por el legislador, lo cual prácticamente nos lleva a pensar en el «no ejercicio» de alguna competencia. Es decir, el control que establece el artículo 61 LRBRL trata de garantizar la sujeción de las corporaciones locales al ordenamiento jurídico, no a una determinada interpretación de la Constitución o a la voluntad política mayoritaria en otra instancia territorial. El artículo 8 CEAL es clarísimo al respecto: «Todo control administrativo de los actos de las Entidades locales no debe normalmente tener como objetivo más que asegurar el respeto a la legalidad y de los principios constitucionales. Sin embargo, tal control podrá extenderse a un control de oportunidad, ejercido por autoridades de nivel superior, respecto de las competencias cuya ejecución se haya delegado en las Entidades locales».

La doctrina ha llegado incluso a apuntar la inconstitucionalidad de esta previsión, por considerarla contraria a la doctrina del TC sobre la autonomía local en sentencias como la 4/81, de 2 de febrero, la 117/84, de 5 de diciembre, la $27 / 87$, de 27 de febrero ${ }^{62}$. En la primera de ellas, sin embargo, el TC admitió la constitucionalidad del artículo 422.1 de la Ley de Régimen Local que habilitaba al Gobierno para disolver los Ayuntamientos y Diputaciones provinciales cuando su gestión resultara gravemente dañosa para los intereses generales. Sí consideró inconstitucional el precepto en lo referente a la disolución gubernativa por gestión gravemente dañosa a los intereses de la propia entidad local. Esto nos lleva a preguntarnos si realmente cuando se propone la disolución de un municipio por un acto o acuerdo que suponga apoyo al terrorismo se están dañando intereses generales o de la propia entidad local. En todo caso, y como he apuntado con anterioridad, el TC ha insistido desde su sentencia 4/81 en la idea de que el control sobre las entidades locales ha de limitarse al de «legalidad» y sin que en ningún caso suponga «controles genéricos o indeterminados que sitúen a las entidades locales en una posición de subordinación o dependencia cuasi jerárquica de la Administración del Estado u otras Entidades territoriales». Incluso la citada sentencia insiste

62 J. M. GIL-Robles y GIL-Delgado, «Art 155. El control extraordinario de las Comunidades Autónomas», Comentarios a la Constitución española de 1978, dirigidos por Óscar AlzaGA. Tomo XI, Cortes Generales. Editoriales de Derecho Reunidas. Madrid, 1998, p. 506. 
en que «los controles de carácter puntual habrán de referirse normalmente a supuestos en que el ejercicio de las competencias de la entidad local incidan en intereses generales concurrentes con los propios de la entidad, sean del Municipio, la Provincia, la Comunidad Autónoma o el Estado».

Cosa distinta, y que incide en el «corazón» mismo de la autonomía local, sería cuestionar la manera en que se ejercen dichas competencias. Por ejemplo, sería de una más que dudosa constitucionalidad cuestionar el pronunciamiento del Pleno, máximo órgano representativo del municipio, en relación a un atentado terrorista o en relación a una medida adoptada por el gobierno central. Ello atentaría contra su autonomía al eliminar los «espacios de discrecionalidad política» que corresponden a la corporación en cuanto órgano representativo de la comunidad, cuya línea política mayoritaria no tiene por qué coincidir con la del Parlamento o con la del gobierno de la nación. Es decir, tendríamos que preguntarnos si acuerdos que supongan, por ejemplo, apoyo a los presos de ETA, o actos que puedan celebrarse en honor de terroristas fallecidos, legitimarían la disolución de la corporación. Creo que sería una interpretación claramente atentatoria contra los márgenes de autonomía política del municipio, por más que refleje lo que HäBERLE ha denominado «paradoja del pluralismo» ${ }^{63}$. Como he tratado de dejar claro en las páginas anteriores, «el hecho de que la orientación política del ente autónomo provenga de la propia decisión democrática de las personas que lo componen impide que le pueda venir impuesta del exterior, especialmente de los órganos centrales del Estado e, incluso, posibilita la existencia de orientaciones diferentes en el Estado y en cada uno de los entes autónomos, en tanto en cuanto prevalezcan en éstos mayorías distintas de la que exista en las Cortes Generales» ${ }^{64}$.

Como bien se ha señalado con respecto a la posibilidad de control del Estado sobre las CCAA que prevé el artículo $155 \mathrm{CE}$, argumentación que creo perfectamente trasladable al control del artículo 61 LRBRL, «es prácticamente imposible que una Comunidad pueda atentar gravemente al interés general de España sin infringir un precepto legal o una norma constitucional. Porque ese «interés general» no es ni puede ser cualquiera

${ }^{63}$ De acuerdo con ella, «allí donde aparezcan teorías o estrategias antipluralistas que supongan momentos prácticos en los que cuestione la propia esencia del pluralismo, será la Constitución pluralista la que deberá ponerse en guardia y contrarrestar tales efectos mediante toda una gama de procedimientos debidamente regulados y preestablecidos». Peter Häberle, Pluralismo y Constitución. Estudios de Teoría Constitucional de la Sociedad Abierta. Tecnos. Madrid, 2002, pp. 115116.

64 Pablo Lucas Verdú y Pablo Lucas Murillo de la Cueva, «Comentario introductorio al Capítulo I del Título VIII», Comentarios a la Constitución española de 1978. Dirigidos por: Óscar Alzaga Villaamil. Tomo X, cit., p. 435. 
que establezca el Gobierno de turno o la mayoría que lo respalda: entenderlo en este sentido equivaldría a suprimir el derecho al autogobierno de las Comunidades Autónomas, al supeditarlo a la orientación política predominante en cada momento en el conjunto del Estado; el artículo 155 ha de interpretarse a la luz de todos los principios constitucionales, entre los cuales está el de autonomía» 65 .

También deberíamos tener en cuenta que el mecanismo previsto en el actual artículo 183 LOREG de nombramiento de la Comisión Gestora que ha de ocuparse de la administración ordinaria de los asuntos de la Corporación disuelta plantearía, sin duda, importantes problemas políticos ya que se configuraría un órgano de composición muy similar al del ayuntamiento disuelto, amén de que la responsabilidad de dicho nombramiento acabaría correspondiendo a fuerzas políticas que se han pronunciado expresamente en contra de esta medida. La solución adoptada por la LO 1/2003, consistente en atribuir la gestión ordinaria a la Diputación Provincial o, en su caso, al órgano competente de la Comunidad Autónoma (art. 183.2 LOREG), no hace sino subrayar las dificultades. En todo caso, la única «salida» posible, y más coherente con la lógica de «defensa del Estado» que parece animar esta medida, sería que la responsabilidad del nombramiento de la Comisión Gestora correspondiera al gobierno central.

Por otra parte, se ha señalado el paralelismo del artículo 61 LRBRL con el artículo 155 CE. Sin embargo, lo primero que debemos señalar es que este artículo no prevé expresamente la disolución de una Comunidad Autónoma. Se limita a establecer que el Gobierno, previo requerimiento al Presidente de la CA, y con la aprobación de la mayoría absoluta del Senado, «podrá adoptar las medidas necesarias para obligar a aquél al cumplimiento forzoso de dichas obligaciones o para la protección del mencionado interés general». El apartado $2^{\circ}$ concreta algo más esa previsión, aunque se limita a prever que el Gobierno pueda dar instrucciones a todas las autoridades de las Comunidades Autónomas. En este caso no se habla de manera expresa de «disolución» de los órganos de la Comunidad Autónoma, entre otras cosas, porque ello supondría una grave contradicción con el carácter indiscutiblemente político —en este caso sí- que se atribuye a las Comunidades Autónomas ${ }^{66}$. Se trata de obligar a las CCAA a

\footnotetext{
65 J. M. GIL-Robles, op. cit., p. 150.

66 No faltan autores que sí admiten la posibilidad de la disolución de los órganos de las CCAA. Es el caso, por ejemplo, de L. Tolivar Alas en El control del Estado sobre las CCAA. Instituto de Estudios de Administración Local. Madrid, 1981. P.187.
} 
que cumplan las obligaciones constitucionales, sin que se llegue a establecer la sanción de la «disolución» de sus órganos.

Como reiteradamente ha señalado la doctrina, se trata de una forma de control excepcional, en cuanto supone una «excepción a la regla constitucional de autogobierno» ${ }^{67}$. Por lo tanto, sólo podrá acudirse cuando no sean suficientes los medios ordinarios de control. Es decir, su aplicación ha de se restrictiva, ya que, como bien ha señalado el Tribunal Constitucional, «no se ajusta al principio de autonomía la previsión de controles genéricos e indeterminados, que impliquen una dependencia jerárquica de las Comunidades Autónomas respecto de la Administración del Estado» (STC 6/1982, de 22 de febrero, FJ 7).

Tanto en el artículo 155 CE como en el artículo 61 LRBRL se exige la intervención del Senado, aunque con respecto a la disolución de las Corporaciones locales no se exige una mayoría específica. Se habla de «previo acuerdo favorable del Senado». El Reglamento del Senado, en su artículo 189, regula su intervención en el procedimiento previsto en el artículo $155 \mathrm{CE}$, pero no contempla su actuación en el del artículo 61 LRBRL. En relación al control del Estado sobre las CCAA, tiene más sentido la intervención del Senado, dado su carácter, al menos formal, de Cámara de representación territorial. Además, el artículo 189 del Reglamento del Senado (RS) prevé que, una vez presentado ante el Presidente de la Cámara el escrito del Presidente del Gobierno en el que se propongan las medidas de control, la Mesa del Senado lo remita, junto a la documentación aneja, a la Comisión General de las Comunidades Autónomas, o bien proceda a constituir una Comisión conjunta en los términos previstos en el artículo 58 RS. Es esta Comisión la que formulará propuesta razonada sobre si procede o no la aprobación solicitada por el Gobierno, con los condicionamientos o modificaciones que, en su caso, sean pertinentes en relación con las medidas proyectadas. Posteriormente el Pleno del Senado debatirá y votará esta propuesta ${ }^{68}$.

Con respecto al procedimiento del artículo 61 LRBRL, el artículo 118.1.c) de la misma ley prevé un informe previo de la Comisión Nacio-

67 José $\mathrm{M}^{\mathrm{a}}$ GIL-Robles y GiL-Delgado, «Art. 155. El control extraordinario de las Comunidades Autónomas», cit., p. 5.

68 Hay que tener en cuenta que se trata de una «autorización» del Senado, no de una mera «convalidación» o «ratificación», por lo que el Gobierno no puede poner en práctica dichas medidas sin aquélla. Por otra parte, la autorización del Senado no puede entenderse como genérica sino provisional y para atender una situación concreta. Véase al respecto E. GARCÍA DE EnTERRía, La ejecución autonómica de la legislación del Estado. Madrid, 1983, pp. 173-176. 
nal de Administración Local ${ }^{69}$, que, en todo caso, no es un órgano representativo de las corporaciones locales ni tampoco una Comisión Parlamentaria ${ }^{70}$.

Igualmente podríamos plantearnos por qué la autorización no corresponde al Congreso, o a las dos Cámaras ${ }^{71}$. Cabe pensar que la caracterización, más formal que real, del Senado como «Cámara de representación territorial» es la que llevó al legislador a optar porque fuera ésta la encargada de autorizar una medida que afecta a uno de los niveles territoriales del Estado. En todo caso, la deficiente configuración, tanto en su composición como en sus competencias, del Senado, nos lleva incluso a cuestionar la oportunidad de esta opción. Por otra parte, en la medida en que el Gobierno disponga de un respaldo mayoritario en ambas Cámaras, la autorización del Senado sería una mera formalidad.

También se ha cuestionado la atribución al gobierno central de la competencia para disolver los ayuntamientos. En concreto, el gobierno catalán anunció cuando se estaba discutiendo la proposición que recurriría la Ley si ésta no atribuyese dicha potestad a las Comunidades Autónomas, por entender que ello supondría una vulneración de las autonomías con competencias en régimen local, como puede ser la catalana o la vasca ${ }^{72}$. La atribución al gobierno central es más acorde con el carácter de instrumento defensivo del interés general y de los principios constitucionales que se le quiso otorgar a la disolución de las corporaciones locales. En todo caso, ello nos llevaría a replantear el debate sobre la posición de las autonomías locales en la estructura territorial del Estado español. Debemos recordar que todos aquellos Estatutos de Autonomía que recogen como competencia exclusiva el régimen local, introducen la salvedad de que la misma ha de entenderse sin perjuicio de lo que dispone el artículo 149.1.18 CE, es decir, se prevé que, en todo caso, han de respetar el marco básico de regulación del régimen local trazado por el legislador estatal ${ }^{73}$. Marco básico

\footnotetext{
${ }^{69}$ Creo que en este procedimiento debería intervenir la Comisión de las Entidades Locales (art. 49.2 RS), constituida el 20 de diciembre de 2002 como comisión permanente no legislativa.

${ }^{70}$ La Comisión Nacional de Administración Local es el órgano permanente para la colaboración entre la Administración General del Estado y la Administración Local. Se integra orgánica y funcionalmente en el Ministerio de Administraciones Públicas. Véase el Reglamento de la misma aprobado por el RD 1431/1997, de 15 de septiembre.

${ }^{71}$ L. Tolivar Alas contempla la posibilidad de que sean las dos Cámaras en el procedimiento previsto en el art. 155, op. cit., p. 187.

72 El País, 29 de octubre de 2002.

73 Véanse el art. 10.4 del Estatuto de Autonomía del País Vasco, el art. 9.8 del Estatuto catalán, el
} 
que diseña la LRBRL, en cuya Exposición de Motivos se afirma que constituye «una ley que ataña a la construcción misma del Estado y al diseño de uno de los ordenamientos jurídico-administrativos que en él se integran». Una ley que, pese a no estar incluida en el llamado «bloque de la constitucionalidad», goza de una especial preeminencia por la función constitucional que cumple ${ }^{74}$. Algo que el propio TC afirmó en su sentencia de 27 de febrero de 1987, según la cual dicha ley «desarrolla la garantía constitucional de la autonomía local, función ordinamental que, al estarle reservada o, lo que es igual, vedada a cualesquiera otras normas, presta a su posición en el ordenamiento en su conjunto una vis específica, no obstante su condición formal de Ley ordinaria». De esta manera, el Estado asume un papel preeminente en la definición de nuestro régimen local, aunque sin olvidar el «carácter bifronte» que, como ha señalado el TC reiteradamente (STC 84/82, 214/89) caracteriza a aquél y, por tanto, la participación también de las CCAA en su concreción ${ }^{75}$. En todo caso, hay que tener en cuenta que la jurisprudencia del TC ha ido evolucionando en el sentido de otorgarle un mayor papel a las CCAA en la configuración del régimen local (SSTC 331/93, de 12 de noviembre; 109/98, de 21 de mayo), lo cual «no significa necesariamente acabar en una exclusiva interiorización del sistema local en el de las CCAA» ${ }^{76}$. De todas maneras, la discusión sobre la atribución al gobierno central no tiene sentido desde el momento en que la disolución de los ayuntamientos supone un medio extraordinario de control de las autonomías locales y, a su vez, una garan-

27.2 del gallego, el 13.3 del andaluz, el art. 8 del de La Rioja, el art. 11.9 del murciano y el art. 35.2 del aragonés.

${ }^{74}$ Se ha afirmado en este sentido que la LRBRL fija el contenido de la garantía institucional de la autonomía local. Fernando Mora, «Régimen jurídico de las entidades locales: la incidencia de la sentencia del Tribunal Constitucional 215/89, de 21 de diciembre, sobre el sistema de fuentes», Revista Española de Derecho Administrativo. No 70, abril-junio 1991, p. 281. Sobre la función constitucional que cumple la LRBRL, véase R. GómEZ-FERRER, «Relaciones entre leyes: competencia, jerarquía y función constitucional», Revista de Administración Pública. $\mathrm{N}^{\circ} 100-102$, mayoagosto 1987, pp. 42-43.

75 No han faltado las críticas a esa caracterización. Por ejemplo, L. PAREJo Alfonso considera que el TC ha sido reticente a precisar la posición constitucional de la instancia local en la estructura del Estado autonómico, «basada en el refugio a su supuesta "naturaleza bifronte", aunque escorada o vencida del lado de las CCAA, que nada dice y todo lo permite y que, por ello mismo, traduce una reticencia a otorgar una dimensión propia a la Administración local desde una idea de ella como mera administración menor-indirecta de las de las instancias superiores, especialmente, por tanto, de la autonómica». «La Ley 30/92 y la Ley 7/85: una valoración global de la integración del régimen básico de la Administración local en el conjunto de las Administraciones públicas», Anuario de Gobierno Local, 1995, p. 47. Véase también su artículo «Estado autonómico y régimen local», Revista Andaluza de Administración Pública. № 44, 2001, pp. 11 ss.

76 Tomás Font i LLovet, «La autonomía local en España a los veinte años de la Constitución: perspectivas de cambio», Anuario de Gobierno Local, 1998, p. 39 
tía del interés general y, como han señalado los partidos mayoritarios, de los principios constitucionales.

En definitiva, creo que la utilización de la vía del artículo 61 LRBRL, no sólo complicaría aún más el clima político en los municipios vascos sino que supondría un grave atentado contra la autonomía local. No creo que la posible solución del «problema vasco» pueda venir a través del recurso a medidas extremas de defensa del Estado o, mejor dicho, de un concreto modelo de Estado, el que defienden los partidos mayoritarios nacionales. Pienso que es necesario revalorizar el entendimiento del Estado desde el pluralismo territorial $\mathrm{y}$, por lo tanto, reivindicar el necesario diálogo para la continuidad de un proceso que se inició con la Constitución y el Estatuto, y que debe continuar avanzando mediante la negociación y el correcto equilibrio entre la «unidad» y la «autonomía», entendiendo siempre aquélla como una «unidad plural que es, también, pluralidad integrada» ${ }^{77}$. Diálogo que, mucho me temo, no será posible mientras que permanezcan en el poder los líderes políticos, tanto nacionales como nacionalistas, que tanto han hecho por radicalizar las posiciones en los últimos tiempos y que tanto han contribuido a tensar la situación política del País Vasco.

77 Pablo Lucas Verdú y Pablo Lucas Murillo de la Cueva, «Comentario introductorio al capítulo I del Título VIII», Comentarios a la Constitución española de 1978, cit., p. 427. 